\title{
OSMOTIC DEHYDRATION OF CUT APPLE: MASS TRANSFER KINETICS AND MICROSTRUCTURAL CHANGES
}

\author{
F.R. Assis ${ }^{\mathrm{a}}$, J. PISSARRA ${ }^{\mathrm{b}}$, R.M.S.C. Morais ${ }^{\mathrm{a}}$ and A.M.M.B. MoraIS ${ }^{\mathrm{a} *}$ \\ ${ }^{\mathrm{a}} \mathrm{CBQF}$ - Centro de Biotecnologia e Química Fina - Laboratório Associado, Escola Superior de Biotecnologia, \\ Universidade Católica Portuguesa, Rua Arquiteto Lobão Vital, 172, 4200-374 Porto. Portugal \\ ${ }^{\mathrm{b}}$ Faculdade de Ciências, Universidade do Porto, Rua do Campo Alegre, s/n, 4169-007 Porto. Portugal
}

(Received: 24 February 2018; accepted: 18 May 2018)

\begin{abstract}
Apple cubes were osmotically dehydrated with $40^{\circ} \mathrm{Bx}$ sucrose and sorbitol solutions. Light microscopy was used to observe the microstructure of fresh and osmotically dehydrated samples. Peleg's model could fit the experimental data and describe the mass transfer kinetics of water loss $(W L)$ and solid gain $(S G)$. The use the sorbitol as osmotic agent, the increase of temperature and concentration of the solution increased the $W L$ during the osmotic dehydration. The average cellular parameters, area and perimeter (size), and circularity, elongation, roundness, and compactness (shape) of fresh samples were $14.28 \pm 6.65 \times 10^{3} \mu \mathrm{m}^{2}$ and $0.486 \mathrm{~mm}$, and $0.73,1.56,0.70,0.83$, respectively. The osmotically dehydrated samples presented a decrease in area, circularity, roundness and compactness and an increase in the elongation of the cells, and these changes were higher in samples treated with sorbitol.
\end{abstract}

Keywords: apple, osmotic dehydration, sorbitol, sucrose, mathematical modelling, microstructure

The osmotic dehydration (OD) allows to preserve fruit reducing their initial water content down to $50 \%$. The osmotic agent most used in the OD of fruit is sucrose because of its effectiveness, convenience, and desirable flavour (LENART, 1996). Alternative solutes have been used, such as sorbitol (ChauHan et al., 2011; Rodríguez et al., 2013; Brochier et al., 2014), which is a prebiotic with proven health properties (ChAuHAn et al., 2011; PAтEL \& Goyal, 2012). Besides, sorbitol is less calorific and has a relative sweetness of around $60 \%$ compared with sucrose (SiLveIRA \& Jonas, 2002).

Most food processes that involve heat and mass transfer cause many macroscopic and microscopic modifications in the plant tissue (Nieto et al., 2004; Lewicki \& PorzecKAPAWLAK, 2005). These structural modifications, consequently, alter the mass transfer mechanisms during these processes (SEGUí et al., 2012). The light microscopy has been used to observe structural changes in osmotically dehydrated products of apple and pumpkin (Quiles et al., 2003; NiETO et al., 2004; MAYOR et al., 2008). In the light microscopy images, these authors observed the folding of cell wall, rupture of cellular membranes, and cellular shrinkage after the osmotic process. Changes in geometrical cellular parameters were also observed.

The higher the difference between the concentration of the solute in the osmotic solution and the food, the greater the mass transfer is (KHAN, 2012). The mass transfer involves water loss $(W L)$ and solid gain $(S G)$, but in some cases a high increase in the $S G$ is not desired. MAYOR and co-workers (2006) osmotically dehydrated pumpkin and found that the concentration of the osmotic solution had more influence on the equilibrium values than the

\footnotetext{
* To whom correspondence should be addressed. Phone: +351 225580050; fax: +351 225090351; e-mail: abmorais@porto.ucp.pt
} 
temperature. During OD of red cabbage with sugar beet molasses, MisLJENOvic and coworkers (2009) noted that the increase of the concentration of the molasses and the immersion time tended to increase the dry matter, consequently, the $S G$.

The objectives of this study were: i) to carry out the OD of apple cubes, using two different solutions with sucrose and sorbitol at $40{ }^{\circ} \mathrm{Bx}$, and to study the effect of the temperature on the $W L$ and $S G$; ii) to test the adequacy of the fitness of Peleg's model to describe the $W L$ and the $S G$ of the product during the OD process; iii) to evaluate the microstructural changes of the apple tissue after the OD with the two different solutes.

\section{Materials and methods}

The osmotic dehydration processes were performed at CBQF of UCP while the light microscopy analyses were carried out at Faculdade de Ciências of UP.

\subsection{Samples}

Apples (Malus spp., variety Royal Gala) were supplied by Campotec, Portugal, and stored at $4{ }^{\circ} \mathrm{C}$. The fruit were washed and sanitized with aqueous solution with $7500 \mathrm{ppm}$ active chlorine for $5 \mathrm{~min}$. Then, they were cut in cubes $(12 \mathrm{~mm}$ ) with a vegetable cutter (Secret de Gourmet, France) and immersed in a solution with $0.9 \%$ sodium chloride for 3 min to prevent enzymatic browning. The samples were blotted gently with tissue paper in order to remove the excess of sodium chloride solution from the surface. The soluble solids content of the apple was $17.0 \pm 0.7^{\circ} \mathrm{Bx}$ (Hand refractometer, Atago, China).

\subsection{Osmotic dehydration process}

The osmotic solutions were prepared with ultra-pure water and commercial sucrose and sorbitol (Fagron Iberica, Spain). The OD was carried out in beakers placed in a shaking incubator (Wiggenhauser, Germany) at constant temperature and agitation (50 r.p.m.). Apple samples were immersed in the osmotic solution at $40^{\circ} \mathrm{Brix}$ and submitted to temperatures of 25,40 , and $60^{\circ} \mathrm{C}$. The mass ratio of sample to solution used was $1: 4$. The apple cubes were removed from the solution at different times. Then, the samples were rinsed with ultra-pure water to remove the solution adhered to the surface and blotted with tissue paper to remove the excess of water from the surface. The experiments were performed in duplicate.

\subsection{Moisture content determination}

The moisture content was determined by placing the fresh and osmotically dehydrated samples in an oven (FP115, Binder, Tuttlingen, Germany) at $105^{\circ} \mathrm{C}$ until constant weight (AOAC, 2002). The determinations were performed in triplicate.

\subsection{Osmotic dehydration parameters and mathematical model}

The parameters of water loss $(W L)$ and solid gain $(S G)$ were determined using the following equations:

$$
W L=\frac{w_{w 0}-w_{w}}{w_{0}}
$$




$$
S G=\frac{w_{s}-w_{s o}}{w_{0}}
$$

where $w_{\mathrm{w} 0}$ is the initial moisture content, $w_{w}$ is the moisture content at time $t, w_{0}$ is the initial weight of the sample, $w_{s}$ is the dry matter at time $\mathrm{t}$ of $\mathrm{OD}$, and $w_{\mathrm{s} 0}$ is the initial dry matter of sample, all in $\mathrm{kg}$.

Peleg's model (1988) was used to fit the $W L$ and $S G$ data. The $W L$ and $S G$ are given by:

$$
W L \text { or } S G=\frac{t}{k_{1}+k_{2} \cdot t}
$$

where $k_{1}$ and $k_{2}$ are the Peleg constants for $W L$ or $S G$.

The constant $k_{1}$ relates to the initial rate of the mass transfer and the constant $k_{2}$ relates to equilibrium values, $W L \infty$ or $S G \infty$, as may be seen below:

$$
\begin{array}{r}
\left(\frac{\mathrm{d}(W L \text { or } S G)}{\mathrm{d} t}\right)_{\mathrm{t} \rightarrow 0}=\lim _{\mathrm{t} \rightarrow 0}\left[\frac{\mathrm{d}\left(\frac{t}{k_{1}+k_{2} \cdot t}\right)}{\mathrm{d} t}\right]=\frac{1}{k_{1}} \\
\lim _{\mathrm{t} \rightarrow \infty}(W L \text { or } S G)=(W L \text { or } S G)_{\infty}=\lim _{\mathrm{t} \rightarrow \infty} \frac{t}{k_{1}+k_{2} \cdot t}=\frac{1}{k_{2}}
\end{array}
$$

\subsection{Light microscopy analysis}

For the analysis by light microscopy, the samples were cut in parallelepipeds $(12 \times 12 \times 15$ $\mathrm{mm}$ ) with the vegetable cutter and immersed in a solution with $0.9 \%$ sodium chloride for 3 minutes. With the aim to obtain a good structural and compositional homogeneity of the samples, the parallelepipeds were taken from the same parts of the fruit (Fig. 1). The samples were blotted gently with tissue paper in order to remove the excess of sodium chloride solution from the surface. These samples were then immersed in $60^{\circ} \mathrm{Bx}$ osmotic solutions of sucrose and sorbitol for 14 hours at $60{ }^{\circ} \mathrm{C}$, using a mass ratio of sample to solution of 1:4. Then, the samples were fixed in $2.5 \%$ glutaraldehyde in $1.25 \%$ PIPES buffer at $\mathrm{pH} 7-7.2$ for 24 hours at room temperature (ca. $20^{\circ} \mathrm{C}$ ) (MAYOR et al., 2008). For the osmotically dehydrated samples, the fixing solution was added to the osmotic solution at the same concentration of the solution at the end of OD, which was 53.6 and $52.4^{\circ} \mathrm{Bx}$ for sucrose and sorbitol, respectively. After that, they were dehydrated in a water/ethanol series and embedded in LR White resin (London Resin Co., Basingstoke, UK). Sections $(6 \mu \mathrm{m})$ of the resin blocks were obtained with a microtome (Jung RM 2035, Leica, Germany). The sections were stained with an aqueous solution Azure II 0.5\%, Methylene Blue 0.5\%, Borax 0.5\% for 30 seconds. After that, they were washed with distilled water and mounted on a glass slide (MAYOR et al., 2008).

The microimages were obtained under a light microscope equipped with a digital camera (BA310, Motic, China) and connected to a computer. The image acquisition was performed with an interface (Motic Images Plus 2.0 ML). The image analysis of the cells was performed using the free software "ImageJ" (version 1.51g), which allows to obtain geometric cellular parameters, such as area, perimeter, length of the major axis, length of the minor axis, circularity, elongation, roundness, aspect ratio, and compactness. 


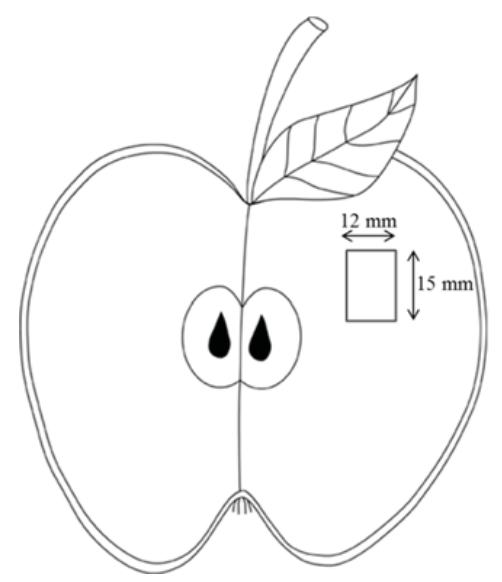

Fig. 1. Location of sampling of apple tissue

\subsection{Statistical analysis}

The statistical analysis was performed using IBM SPSS ${ }^{\circledR}$ Statistics 20.0 for Windows $^{\circledR}$ (2012, SPSS Inc., Chicago, USA). The normality of the data was tested using the KolmogorovSmirnov test. When the normality of data was not verified, an alternative non-parametric test, Kruskal-Wallis, was used. In this case, the Mann-Whitney test was subsequently performed to detect which values were significantly different.

The adequacy of the model fit was evaluated by the determination coefficient $\left(\mathrm{R}^{2}\right)$ and by the residual analysis. This was performed in order to check the assumptions of independence, randomness, and normality (mean equal to zero and constant variance). Randomness and homoscedasticity was assessed by visual inspection of the dispersion of residuals $v s$. the values predicted by the model. The normality of the residuals was evaluated by Kolmogorov-Smirnov test.

In all tests and analysis performed, the significance level assumed was $5 \%$.

\section{Results and discussion}

\subsection{Mass transfer kinetics}

Higher $W L$ and $S G$ rates were noted in the first two hours of the process (Figs 2 and 3), which were probably due to the large differences of osmotic pressure between the solutions and the samples at the beginning of the process. Also during this period, these rates were higher in the OD with sorbitol solutions. This might be explained by the lower viscosity of sorbitol solutions attributed to the higher molar concentration of these solutions, $2.198 \mathrm{M}$ in comparison with $1.170 \mathrm{M}$ for sucrose solutions $\left(40^{\circ} \mathrm{Bx}\right)$, as discussed by Assis and coworkers (2017).

Peleg's model satisfied all assumptions described above in section 1.6, and it was able to describe the mass transfer kinetics of $W L$ and $S G$ of apple cubes at the OD conditions used. The $\mathrm{R}^{2}$ values of the fits of $W L$ were higher than 0.95 (Table 1). The initial rate of $W L$, 
reflected in $1 / k_{1}$, was higher using sorbitol for all tested conditions. $1 / k_{1}$ also presented the highest value in experiments with the sorbitol solution at $60{ }^{\circ} \mathrm{C}$. The increase in temperature increased the rate of the $W L$. The equilibrium values of $W L\left(1 / k_{2}\right)$ varied from 0.312 to 0.552 $\mathrm{h} \mathrm{kg} \mathrm{DM} / \mathrm{kg}$ water. At 25 and $40^{\circ} \mathrm{C}$, the $W L$ at equilibrium was higher in experiments with sorbitol in relation to sucrose.

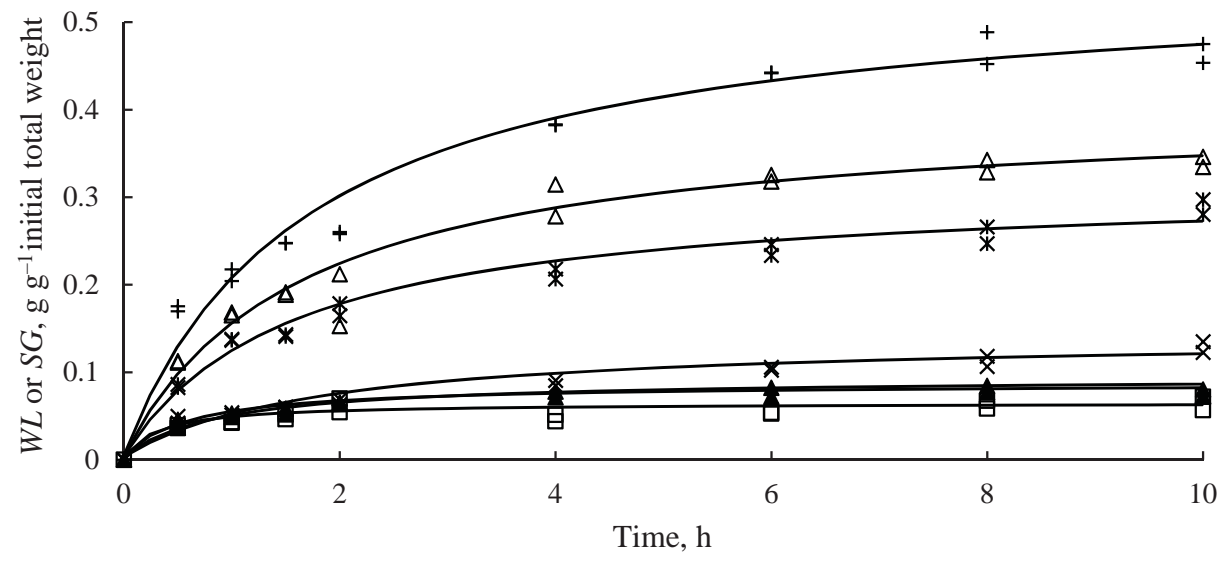

Fig .2. Experimental data and the fit of Peleg's model of $W L$ and $S G$ of apple cubes osmotically dehydrated in a $40^{\circ} \mathrm{Bx}$ sucrose solution and at 25,40 , and $60^{\circ} \mathrm{C}$, using a mass ratio of sample to solution of 1:4. $*$ : WL $25^{\circ} \mathrm{C}$; $\triangle: W L 40{ }^{\circ} \mathrm{C} ;+: W L 60{ }^{\circ} \mathrm{C} ; \boldsymbol{\Delta}: S G 25^{\circ} \mathrm{C} ; \square: S G 40{ }^{\circ} \mathrm{C} ; \times: S G 60^{\circ} \mathrm{C}$; — Peleg's model fit.

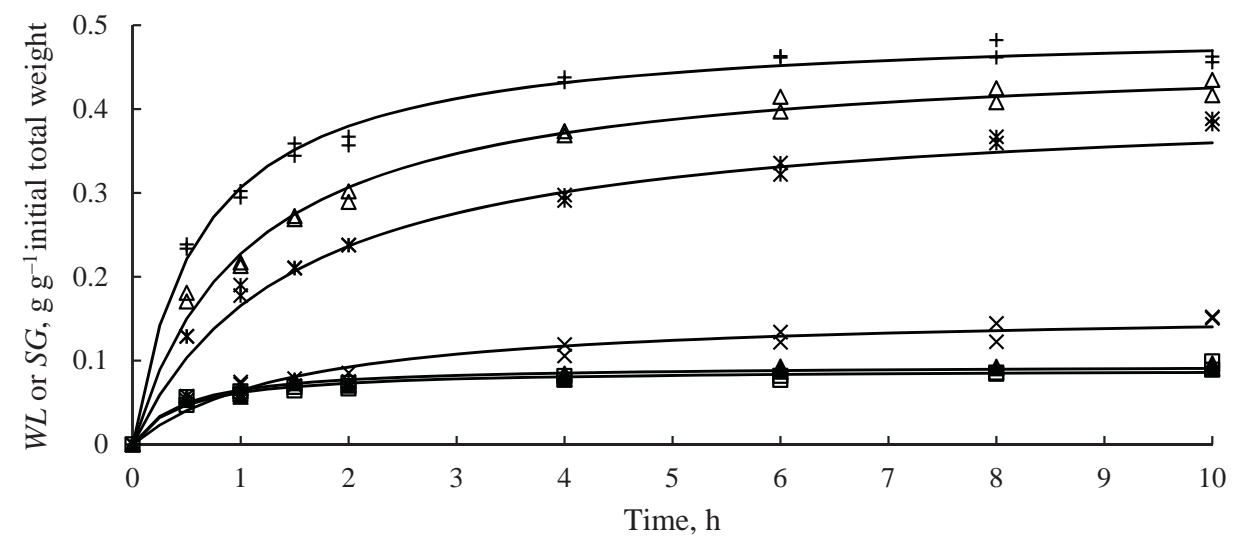

Fig. 3. Experimental data and the fit of Peleg's model of $W L$ and $S G$ of apple cubes osmotically dehydrated in a $40^{\circ} \mathrm{Bx}$ sorbitol solution and at 25,40 , and $60^{\circ} \mathrm{C}$, using a mass ratio of sample to solution of 1:4. * :WL $25^{\circ} \mathrm{C}$; $\triangle: W L 40{ }^{\circ} \mathrm{C}$; +: $W L 60{ }^{\circ} \mathrm{C} ; \boldsymbol{\Delta}: S G 25^{\circ} \mathrm{C} ; \square: S G 40{ }^{\circ} \mathrm{C}$; $\times: S G 60{ }^{\circ} \mathrm{C}$; — Peleg's model fit. 
Table 1. Parameters of the fit of Peleg's model of $W L$ and $S G$ during OD of apple cubes at $40^{\circ} \mathrm{Bx}$ and mass ratio of sample to solution $1: 4$

\begin{tabular}{|c|c|c|c|c|c|c|c|}
\hline \multirow{3}{*}{$\begin{array}{l}\text { Temperature } \\
\left({ }^{\circ} \mathrm{C}\right)\end{array}$} & \multirow[t]{3}{*}{ Solute } & \multicolumn{6}{|c|}{ Peleg } \\
\hline & & \multicolumn{3}{|c|}{$W L$} & \multicolumn{3}{|c|}{$S G$} \\
\hline & & $\begin{array}{c}k_{1} \pm \text { margin } \\
\text { of error } \\
\left(\mathrm{h} \mathrm{kg} \mathrm{kg}^{-1}\right)\end{array}$ & $\begin{array}{c}k_{2} \pm \text { margin } \\
\text { of error } \\
\left(\mathrm{kg} \mathrm{kg}^{-1}\right)\end{array}$ & $\mathrm{R}^{2}$ & $\begin{array}{c}k_{1} \pm \text { margin } \\
\text { of error } \\
\left(\mathrm{h} \mathrm{kg} \mathrm{kg}^{-1}\right)\end{array}$ & $\begin{array}{c}k_{2} \pm \text { margin } \\
\text { of error } \\
\left(\mathrm{kg} \mathrm{kg}^{-1}\right)\end{array}$ & $\mathrm{R}^{2}$ \\
\hline 25 & sucrose & $5.03 \pm 0.86$ & $3.21 \pm 0.22$ & 0.974 & $7.28 \pm 1.76$ & $11.90 \pm 0.71$ & 0.957 \\
\hline 25 & sorbitol & $3.34 \pm 0.44$ & $2.39 \pm 0.12$ & 0.985 & $4.84 \pm 1.18$ & $10.55 \pm 0.54$ & 0.961 \\
\hline 40 & sucrose & $4.06 \pm 0.89$ & $2.50 \pm 0.23$ & 0.959 & $5.49 \pm 3.64$ & $16.18 \pm 1.88$ & 0.804 \\
\hline 40 & sorbitol & $2.27 \pm 0.26$ & $2.13 \pm 0.09$ & 0.989 & $5.02 \pm 1.41$ & $11.14 \pm 0.65$ & 0.949 \\
\hline 60 & sucrose & $3.09 \pm 0.58$ & $1.81 \pm 0.15$ & 0.969 & $13.13 \pm 3.50$ & $7.15 \pm 0.85$ & 0.937 \\
\hline 60 & sorbitol & $1.26 \pm 0.14$ & $2.00 \pm 0.06$ & 0.991 & $9.26 \pm 2.52$ & $6.21 \pm 0.67$ & 0.934 \\
\hline
\end{tabular}

Margin of error is the half width of the confidence interval at $95 \%$.

The $\mathrm{R}^{2}$ values of the fits of $S G$ were higher than 0.8 . The solute did not show an influence on the initial rate of $S G$ ( $k_{1}$-values). The experiments carried out at $60^{\circ} \mathrm{C}$ resulted in a lower $S G$, while no significant differences were observed between 25 and $40{ }^{\circ} \mathrm{C}$. In relation to $k_{2}$ parameter, the use of sorbitol as osmotic agent promoted a higher $S G$ at the end of the process at 25 and $40{ }^{\circ} \mathrm{C}$.

A similar behaviour for experiments at $60^{\circ} \mathrm{Bx}$ (Assis et al., 2017) and $40^{\circ} \mathrm{Bx}$ was noted: the same trend in $k_{1}$ parameter was noted, and the $W L$ increased with temperature. With respect to the $W L$, experiments with sucrose and sorbitol did not follow the same trend in what concerns $k_{1}$ parameter, but $W L$ tended to be higher in experiments at $60{ }^{\circ} \mathrm{Bx}$ than at 40 ${ }^{\circ} \mathrm{Bx}$. At the equilibrium ( $1 / k_{2}$-values), the samples treated with $60{ }^{\circ} \mathrm{Bx}$ solutions presented higher $W L$ than the ones treated with $40^{\circ} \mathrm{Bx}$. The results of LAZARIDES and co-workers (1995) obtained in OD of apple slices were in agreement with these findings. With respect to the $S G$, there were no significant differences in the initial rate of $S G$ between $\mathrm{OD}$ at $40^{\circ} \mathrm{Bx}$ and OD at $60{ }^{\circ} \mathrm{Bx}$, neither at 25 nor at $40{ }^{\circ} \mathrm{C}$, but, at the end of the process, the $S G$ was higher in samples treated with $60^{\circ} \mathrm{Bx}$ solutions.

Roopa and co-workers (2012) observed that the increase of the solute concentration, solution temperature, and dehydration time increased the $W L$ and the $S G$ of carambola slices. PALOu and co-workers (1994) also used Peleg's equation (PELEG, 1988) to describe the mass transfer kinetics during the OD of papaya. They found the same $k_{1}$ for $S G$ during OD in 60 and $70{ }^{\circ} \mathrm{Bx}$ sucrose syrups and a lower $k_{2}$ for $70{ }^{\circ} \mathrm{Bx}$. WALISZEwSKI and co-workers (2002) dehydrated pineapple slabs with sucrose solutions, and found that the $W L$ and $S G$ at the equilibrium were significantly higher in the OD with more concentrated solutions.

\subsection{Microscopy results}

After 14 hours of $\mathrm{OD}$ at $60^{\circ} \mathrm{Bx}$, it was considered that the equilibrium was achieved, i.e., the maxima $W L$ and $S G$ occurred. The initial moisture content of the fresh apples was $5.431 \pm 0.205$ $\mathrm{kg}$ water $/ \mathrm{kg} \mathrm{DM}$. At the end of the OD process, the moisture content was reduced to $0.966 \pm 0.028$ and $1.034 \pm 0.040 \mathrm{~kg}$ water $/ \mathrm{kg} \mathrm{DM}$, using sucrose and sorbitol solutions, respectively. Thus, both solutes resulted in a moisture loss of around $80 \%$. In a previous work, Assis and co-workers (2017) also observed that, at the end of the OD process, these 
two solutes resulted in the same $W L$. However, the solute used in the osmotic solution had an influence on the initial $W L$ rate.

The microscopy analysis of the apple parenchyma was performed before (control) and after the OD with sucrose and sorbitol (Fig. 4). For this part of the study, the OD was performed with $60{ }^{\circ} \mathrm{Bx}$ solutions, because $W L$ at the equilibrium was higher at this concentration than at $40^{\circ} \mathrm{Bx}$, as discussed above.

The cells submitted to the osmotic treatment presented different forms: the cells of the fresh sample were round and the ones of the dehydrated samples were wrinkled. The presence of intercellular spaces could also be noted (Fig. 4B and C). In Figure 5, it is possible to observe a region with vascular site. The cells near this site present different orientation and irregular shape. Therefore, these were not considered in the measurements.

A

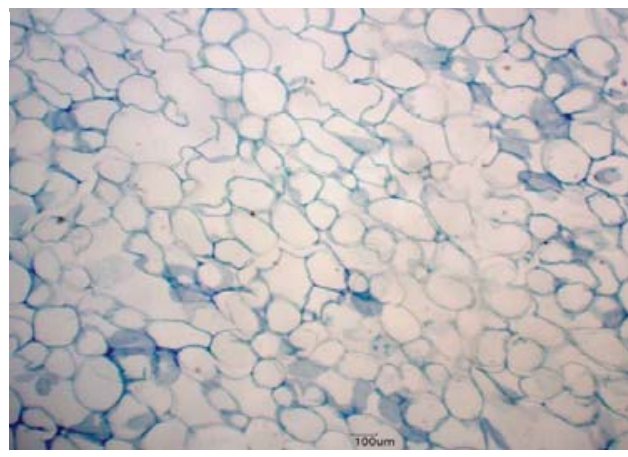

B

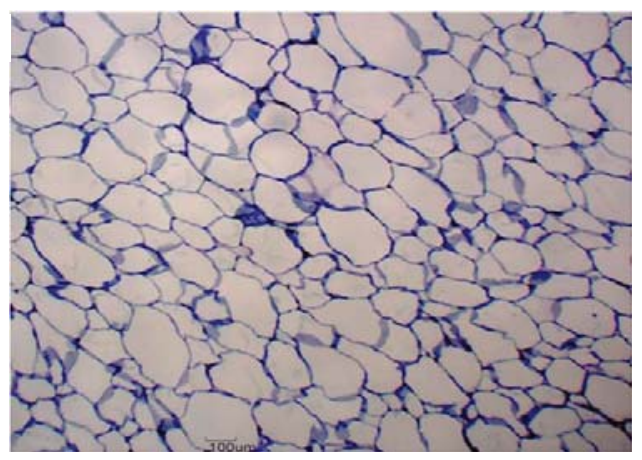

C

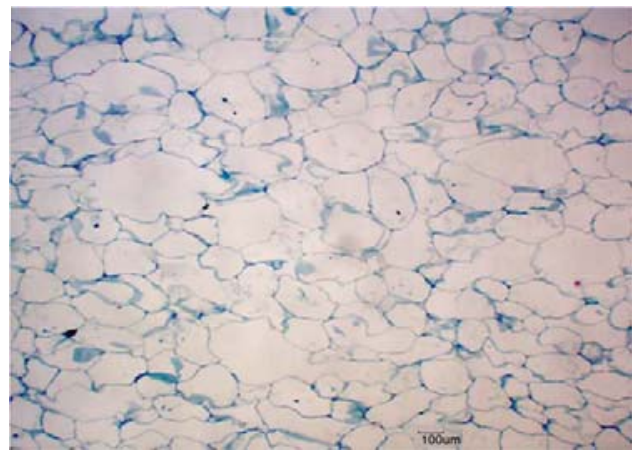

Fig. 4. Microstructure of apple parenchyma analysed before (A) and after the osmotic dehydration with sucrose (B) and sorbitol (C) 


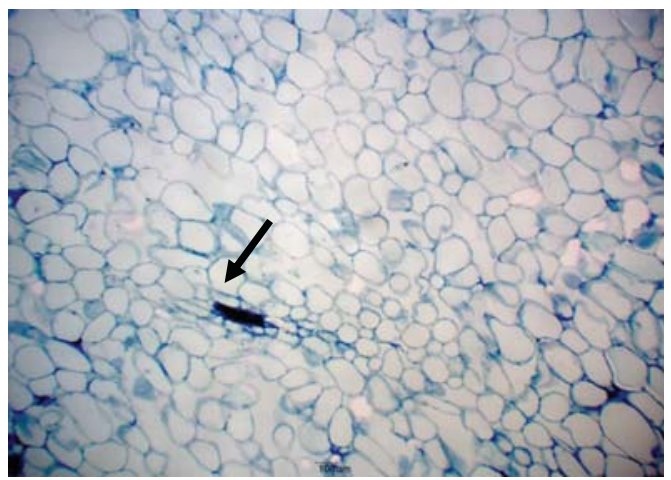

Fig. 5. Microstructure of apple parenchyma with vascular site (arrow)

The area of the cells of fresh samples, $14.28 \pm 6.65 \times 10^{3} \mu \mathrm{m}^{2}$ (Table 2), is in the range of those obtained by Lewicki and Pawlak (2003), Lewicki and Porzecka-Pawlak (2005), and MAYOR and co-workers (2005) for different apple varieties. The area decreased significantly with the osmotic treatment, but there were no significant differences between the solutes used, sucrose and sorbitol. However, the perimeter of the cells was not affected by the OD (Table 2). MAYOR and co-workers (2008) also observed that the area of the tissue cells of pumpkin decreased and their perimeter was maintained during the OD process.

\begin{tabular}{|c|c|c|c|c|c|c|}
\hline $\begin{array}{l}\text { Pre- } \\
\text { treatment }\end{array}$ & $\begin{array}{l}\text { Area } \times 10^{-3} \\
\left(\mu \mathrm{m}^{2}\right)\end{array}$ & $\begin{array}{l}\text { Perimeter } \\
(\mu \mathrm{m})\end{array}$ & Circularity & Elongation & Roundness & Compactness \\
\hline Fresh & $14.28 \pm 6.65^{\mathrm{a}}$ & $485.6 \pm 128.4^{\mathrm{a}}$ & $0.73 \pm 0.11^{\mathrm{a}}$ & $1.56 \pm 0.33^{\mathrm{c}}$ & $0.70 \pm 0.12^{\mathrm{a}}$ & $0.83 \pm 0.07^{\mathrm{a}}$ \\
\hline $\begin{array}{l}\text { OD with } \\
\text { sucrose } \\
\text { solution }\end{array}$ & $13.60 \pm 8.07^{\mathrm{b}}$ & $487.8 \pm 137.9^{\mathrm{a}}$ & $0.71 \pm 0.09^{\mathrm{b}}$ & $1.60 \pm 0.34^{\mathrm{b}}$ & $0.65 \pm 0.14^{\mathrm{b}}$ & $0.80 \pm 0.09^{\mathrm{b}}$ \\
\hline $\begin{array}{l}\text { OD with } \\
\text { sorbitol } \\
\text { solution }\end{array}$ & $12.91 \pm 7.30^{\mathrm{b}}$ & $497.5 \pm 159.2^{\mathrm{a}}$ & $0.64 \pm 0.11^{\mathrm{c}}$ & $1.90 \pm 0.51^{\mathrm{a}}$ & $0.56 \pm 0.16^{\mathrm{c}}$ & $0.74 \pm 0.11^{\mathrm{c}}$ \\
\hline
\end{tabular}

Margin of error is the half width of the confidence interval at $95 \%$.

Different letters in each column mean significantly different values at $\mathrm{P}<0.05$.

At the end of the osmotic process, folding of the cell wall, plasmolysis, and cellular shrinkage were observed (Figs 4B and C). No differences were observed in the intercellular spaces, but there was a reduction of the volume induced by the shrinkage of the samples. The OD affected all shape parameters. Roundness, compactness, and elongation of the fresh sample were $0.70,0.83$, and 1.56 , respectively (Table 2 ). These values are near the values found by KARUNASENA and co-workers (2014) for the same apple variety. The roundness and compactness decreased after the OD process and the cells became more elongated (Table 2). The maximum decrease in roundness and the highest elongation were obtained in samples osmotically dehydrated with sorbitol solutions. The circularity was also affected by the OD 
process. The highest reduction (from 0.73 to 0.64 ) was observed for sorbitol solutions. The decrease of this shape parameter could be explained by the fact that the initial $W L$ was higher when the sorbitol was used as osmotic agent, thus, causing more changes in the structure of the tissue in comparison with the tissue of the samples osmotically dehydrated with sucrose solution.

\section{Conclusions}

Peleg's model was able to describe the mass transfer kinetics of water loss and solid gain in the osmotic dehydration of apple cubes in $40^{\circ} \mathrm{Bx}$ sucrose and sorbitol solutions. The use of sorbitol, the increase of the temperature and solute concentration increased the water loss during the process. This osmotic dehydration process resulted in shrinkage of the cells of the apple tissues and, consequently, in volume reduction, plasmolysis and folding of the cell walls. It caused significant changes in size and shape parameters of the cells, and the use of sorbitol as osmotic agent enhanced these changes.

This work was supported by National Funds from FCT - Fundação para a Ciência e Tecnologia through project UID/ Multi/50016/2013. The first author acknowledges the financial support of CAPES (1528/13-0). The authors also acknowledge Campotec for graciously supplying the apples for this study.

\section{References}

AOAC (2002): AOAC. Association of the Official Analytical Chemists - Official Methods of Analysis, Official Method 934.06.

Assis, F.R., Morais, R.M.S.C. \& Morais, A.M.M.B. (2017): Mathematical modelling of osmotic dehydration kinetics of apple cubes. J. Food Process. Pres., 41. DOI: 10.1111/jfpp.12895.

Brochier, B., MARCZAK, L.D.F. \& NoreÑA, C.P.Z. (2014): Osmotic dehydration of yacon using glycerol and sorbitol as solutes: Water effective diffusivity evaluation. Food Bioprocess Tech., 8, 623-636.

Chauhan, O.P., Sing, A., Singh, A., Raju, S. \& Bawa, A.S. (2011): Effects of osmotic agents on colour, textural, structural, thermal, and sensory properties of apple slices. Int. J. Food Prop., 14, 1037-1048.

Karunasena, H.C.P., Hesami, P., Senadeera, W., Gu, Y.T., Brown, R.J. \& Oloyede, A. (2014): Scanning electron microscopic study of microstructure of Gala apples during hot air drying. Dry. Technol., 32, 455-468.

KHAN, M.R. (2012): Osmotic dehydration technique for fruits preservation - A review. Pak. J. Food Sci., 22, 71-85.

LazArides, H.N., Katsanidis, E. \& Nickolaidis, A. (1995): Mass transfer kinetics during osmotic preconcentration aiming at minimal solid uptake. J. Food Eng., 25, 151-166.

Lenart, A. (1996): Osmo-convective drying of fruits and vegetables: Technology and application. Dry. Technol., 14, 391-413.

Lewicki, P.P. \& PAWLAK, G. (2003): Effect of drying on microstructure of plant tissue. Dry. Technol., 21 , $657-683$.

Lewicki, P.P. \& Porzecka-Pawlak, R. (2005): Effect of osmotic dewatering on apple tissue structure. J. Food Eng., $66,43-50$.

Mayor, L., Moreira, R., Chenlo, F. \& Sereno, A.M. (2006): Kinetics of osmotic dehydration of pumpkin with sodium chloride solutions. J. Food Eng., 74, 253-262.

Mayor, L., Pissarra J. \& Sereno, A.M. (2008): Microstructural changes during osmotic dehydration of parenchymatic pumpkin tissue. J. Food Eng., 85, 326-339.

Mayor, L., Silva, M.A. \& Sereno, A.M. (2005): Microstructural changes during drying of apple slices. Dry. Technol., 23, 2261-2276.

Misluenovic, N., Koprivica, G., Levic, L., Filipcev, B. \& Kuljanin, T. (2009): Osmotic dehydration of red cabbage in sugar beet molasses: Mass transfer kinetics. Acta Period. Technol., 40, 145-154. 
Nieto, A.B., Salvatori, D.M., Castro, M.A. \& Alzamora, S.M. (2004): Structural changes in apple tissue during glucose and sucrose osmotic dehydration: Shrinkage, porosity, density and microscopic features. J. Food Eng., 269-278.

Palou, E., López-Malo, A., Argaiz, A. \& Welti, J. (1994): The use of Peleg's equation to model osmotic concentration of papaya. Dry. Technol., 12, 965-978.

Patel, S. \& Goyal, A. (2012): The current trends and future perspectives of prebiotics research: A review. 3 Biotech, $22,115-125$.

Peleg, M. (1988): An empirical model for the description of moisture sorption curves. J. Food Sci., 53, $1216-1219$.

Quiles, A., Pérez-Munuera, I., Hernando. I. \& Lluch, M.A. (2003): Impact of mass transport on microstructure of Granny Smith apple parenchyma during osmotic dehydration. J. Sci. Food Agr., 83, 425-429.

Rodríguez, M.M., Arballo, J.R., Campañone, L.A., Cocconi, M.B., Pagano, A.M. \& Mascheroni, R.H. (2013): Osmotic dehydration of nectarines: Influence of the operating conditions and determination of the effective diffusion coefficients. Food Bioprocess Tech., 6, 2708-2720.

Roopa, N., Chauhan, O.P., Raju, P.S., Das Gupta, D.K., Singh, R.K.R. \& Bawa, A.S. (2012): Process optimization for osmo-dehydrated carambola (Averrhoa carambola L) slices and its storage studies. J. Food Sci. Tech., 51, 2472-2480.

Seguí, L., Fito, P.J. \& Fito, P. (2012): Understanding osmotic dehydration of tissue structured foods by means of a cellular approach. J. Food Eng., 110, 240-247.

Silveira, M. \& Jonas, R. (2002): The biotechnological production of sorbitol. Appl. Microbiol. Biot., 59, 400-408.

Waliszewski, K.N., Delgado, J.L. \& García, M.A. (2002): Equilibrium concentration and water and sucrose diffusivity in osmotic dehydration of pineapple slabs. Dry. Technol., 20, 527-538. 